Demi van den Broek onderzocht de ervaringen met werken tijdens de Covid-19-pandemie. Dat deed ze bij verpleegkundigen van Centrum Ouderen- en Ziekenhuispsychiatrievolwassenen groep 1 en 2 van Reinier van Arkel in Den Bosch.

\title{
Geraakt door de Covid-19-pandemie
}

\begin{abstract}
Resultaten
Praktijkprobleem

De coronacrisis legt een enorme druk op de gezondheidszorg en het zorgpersoneel. Dit heeft mogelijk negatieve gezondheidsgevolgen voor verpleegkundigen, zoals stress, slapeloosheid en angst. Zo ook voor verpleegkundigen werkzaam op de afdeling Centrum Ouderen- en Ziekenhuispsychiatrie (COZ)-volwassenen groep 1 en 2 van Reinier van Arkel.Deze afdeling biedt klinische behandeling aan volwassenen met psychiatrische en psychosociale hulpvragen. Voorbeelden: depressieve klachten, angstproblematiek, psychotische problematiek, onbegrepen lichamelijke klachten, psychiatrische problemen gerelateerd aan zwangerschap en bipolaire stoornissen. Tijdens de Covid-19-periode was de afdeling COZ-volwassenen groep 2 gedurende de eerste coronagolf gesloten en werd een Covid-19-unit geopend. Het gevolg was dat verpleegkundigen van COZ-volwas-

Verpleegkundigen voelden zich door

Covid-19 beperkt in hun werk. De meesten hebben de complexiteit van de cliëntenpopulatie op de Covid-19-unit als hoog ervaren. Verpleegkundigen gaven aan dat zij onder hoge werkdruk kwamen te staan door het hoge ziekteverzuim, het openen van de Covid-19-unit, het moeilijker verwijzen van cliënten, het werken met invalkrachten en extra taken. Verpleegkundigen waren moe en konden zich minder goed opladen. Ze voelden zich weleens gefrustreerd, gestrest en machteloos. In het team was het gevoel van teamspirit afgenomen. Verpleegkundigen gaven ook aan dat belangrijke

Demi van den Broek Leeftijd: 24

Is: hbo-verpleegkundige in de psychiatrie Opleiding: hbo-

verpleegkunde Avans Hogeschool, Den Bosch, afgestudeerd in juni 2021 randvoorwaarden om hun werk goed uit te kunnen voeren afwezig waren. Zo werden communicatie, waardering, een vast aanspreekpunt op de afdeling, een pool van vaste invalkrachten en bijscholing over Covid-19 gemist.
\end{abstract} senen groep 1 en 2 regelmatig met invalkrachten werkten, maar ook de nieuwe Covid-19-gerelateerde zorg uitvoerden. Ik wilde weten hoe verpleegkundigen van COZ-volwassenen groep 1 en 2 het werken tijdens de Covid-19-pandemie hebben ervaren.

\section{Methode}

Met interviews zijn de ervaringen van negen verpleegkundigen in kaart gebracht. De respondenten zijn geselecteerd op basis van leeftijd, functie, ervaringsjaren en achtergrond. Ook werd gekeken of een verpleegkundige wel of niet is getroffen door corona. De interviews zijn afgenomen via face-to-face-gesprekken en getranscribeerd en gecodeerd voor analyse. Om de betrouwbaarheid en validiteit van dit onderzoek te verhogen, is member checking en peer debriefing toegepast.

\section{Toepassing in de praktijk}

Op basis van de resultaten zijn drie aanbevelingen gedaan: het inzetten van een verpleegkundige coördinator, het inzetten van vaste invalkrachten en het aanbieden van bijscholing over Covid-19.

Inmiddels werk ik als beginnend verpleegkundige op de afdeling waar ik onderzoek heb gedaan. Ik ben blij te zien dat de aanbevelingen geïmplementeerd worden; ik zie al verbetering op de werkvloer. Zo wordt de verpleegkundige coördinator effectief ingezet, waardoor het team zich meer gehoord voelt en de communicatie is verbeterd. Het bespreekbaar maken van emotionele belasting is daarmee laagdrempelig. Ook wordt de bijscholing Covid-19 ingezet om de kennis te vergroten bij verpleegkundigen. Nader onderzoek is nodig om na te gaan of de stress, frustratie en machteloosheid bij verpleegkundigen daadwerkelijk zijn afgenomen. 